\title{
Expression of Lipolytic Genes in the Adipose Tissue of Pregnant and Lactating Holstein Dairy Cattle ${ }^{1}$
}

\author{
J. M. Sumner and J. P. McNamara ${ }^{2}$ \\ Department of Animal Sciences, Washington State University, Pullman 99164-6351
}

\begin{abstract}
The objective of this study was to determine the expression of $\beta$-adrenergic receptors, hormone-sensitive lipase, and its cofactor perilipin in adipose tissue, and their relationships to rates of lipolysis and body fat use in Holstein dairy cattle during late pregnancy and lactation. Twenty Holstein dairy cattle were grouped by lactation number (1,2, and 3 or more), and subcutaneous adipose tissue was sampled to measure lipolytic rates and gene expression. The 305-d mature-equivalent yields (305ME) for first, second, and third or higher parity cows were $13,220,15,659$, and $13,890 \mathrm{~kg}$ [standard error of the means (SEM) 931]. Milk fat and protein averaged 3.55 and $3.3 \%$, across all parities. Milk production at $30 \mathrm{~d}$ in milk (DIM) was $30.7 \mathrm{~kg} / \mathrm{d}$ (3.4) with $3.6 \%$ fat and $2.7 \%$ protein; and at 90 DIM was $47.5 \mathrm{~kg} / \mathrm{d}$ (1.5) with $3.4 \%$ fat and $2.9 \%$ protein. Body weight and body condition score (BCS), measured at $-30,30,90$, and 270 DIM averaged $697,605,652$, and $693 \mathrm{~kg}$ and 3.3, 2.4, 2.8, and 2.8 BCS units. Adipose tissue was extracted for RNA and tissue was incubated to measure basal and stimulated lipolysis. Basal lipolysis increased following parturition, and basal and stimulated lipolysis peaked at 90 DIM. The $\mathrm{B}_{1}, \mathrm{~B}_{2}$, and $\mathrm{B}_{3}$ adrenergic receptors (AR) were expressed at all time points, as shown by PCR and agarose gel analysis as well as real-time reverse transcription-PCR. Expression of $B_{1} A R$, relative to that at $d-30$, increased 170 , 72 , and $112 \%$ at 30,90 , and 270 DIM. Expression of $B_{2}$ $\mathrm{AR}$ increased 75, 121, and $100 \%$; and that of $\mathrm{B}_{3} \mathrm{AR}$ increased 111, 125, and 69\%. Expression of hormonesensitive lipase increased 180, 359, and $47 \%$ at the same time points. Expression of perilipin increased 227, 1,847 , and $126 \%$. The greatest expression of these 5
\end{abstract}

\footnotetext{
Received April 23, 2007.

Accepted August 6, 2007

${ }^{1}$ This paper published with partial support from Kemin Agri Foods North America, Inc., Des Moines, Iowa, and the Agricultural Research Center, Washington State University. This paper published in conjunction with the NC-1009 CSREES Regional Research Project "Protein Synthesis in Lactating Dairy Cattle."

${ }^{2}$ Corresponding author: mcnamara@wsu.edu
}

genes corresponded with the fastest rates of lipolysis at 90 DIM. This work demonstrates that an increase in the expression of $\beta$-adrenergic receptors is part of the multifaceted regulation of lipolysis in dairy cattle. Key words: gene expression, adipose, hormone-sensitive lipase, perilipin

\section{INTRODUCTION}

The primary role of adipose tissue is to store fatty acids for use in the support of productive functions. The transition period from gestation into lactation is a period of metabolic stress, including a rapid increase in milk secretion, a slower rise in feed intake, and resultant negative energy balance and body fat mobilization. The dairy cow responds to negative energy balance with a decrease in lipogenesis and an increase in lipolysis in the adipose tissue (McNamara and Hillers, 1989). Some dairy cattle respond with a rate of lipolysis in excess of what is needed by the body to maintain itself and produce milk, whereas others increase feed intake rapidly and lose significantly less body fat (McNamara and Hillers, 1989; McNamara, 2004). Excessive lipolysis results in the accumulation of lipid in the liver, ketosis, and can further result in other metabolic and reproductive problems (Drackley et al., 2006).

Lipolysis is under the control of endocrine factors and the sympathetic nervous system. Tissue response elements include the $\beta$-adrenergic receptor (AR) subtypes $\left(\mathrm{B}_{1}, \mathrm{~B}_{2}, \mathrm{~B}_{3}\right)$, and expression and activation of hormone-sensitive lipase (HSL) and perilipin (Bauman and Vernon, 1993; McNamara, 1994; Barnes, 1995; Londos et al., 1996). Previous work in this laboratory has shown that responsiveness to adrenergic stimulation increases during lactation, is related to rates of milk production, and is greater in animals of greater genetic merit for milk production (McNamara and Hillers, 1989; McNamara et al., 1992; McNamara and Valdez, 2005). It has not been determined whether expression of the genes listed above changes during lactation in dairy cattle. In ponies, expression of $\mathrm{B}_{2} \mathrm{AR}$ does not appear to change during lactation (Carrington et al., 2003); however, those animals do not lose body fat at the rates of dairy cattle, nor have they been selected 
for milk production. It was also unknown if the adipose tissue of dairy cattle expresses the colipase, perilipin, which has been shown to be necessary for normal lipolysis (Londos et al., 1996). Therefore, the hypothesis of this experiment was that expression of key genes known to regulate lipolysis in adipose tissue increases during lactation. These genes include $\beta$-AR subtypes $\mathrm{B}_{1}, \mathrm{~B}_{2}$, and $\mathrm{B}_{3}$, HSL and its cofactor, perilipin. One objective was to evaluate changes in the expression of the $3 \beta$-AR subtypes and HSL during the transition period and lactation. Another objective was to determine if perilipin is expressed in bovine adipose tissue and if the expression changes during transition and lactation. The final objective was to determine if the expression of these genes was correlated with rates of lipolysis, body energy balance, and body fat use.

\section{MATERIALS AND METHODS}

\section{Animals and Housing}

Twenty cows were selected from the Knott Dairy Herd (Pullman, WA) based on parity and milk production. Four primiparous animals, 6 second-lactation animals, and 10 animals of third or greater lactation number were used. Animals were selected to be in the top $25 \%$ of the herd for milk production based upon 305-d mature-equivalent yield (305ME) values. All animals received similar diets at similar stages of lactation. Dry cows were housed in a freelot and lactating cows were housed in a free-stall barn. Diets were formulated to meet or exceed nutrient requirements for milk production as recommended by NRC (2001). Pregnant animals were fed ad libitum prepartum diets that were $44 \%$ alfalfa haylage, $44 \%$ orchardgrass hay, and $12 \%$ concentrate mix ( $80.3 \%$ ground corn; $11.9 \%$ soybean meal, $5 \%$ molasses, and $2.8 \%$ vitamin and mineral mixes) on a DM basis. Lactating cow diets were also formulated to meet or exceed nutrient requirements as recommended by NRC (2001; Table 1). Milk production and composition data were gathered from the monthly test-day DHIA records for the farm, and milk composition analysis was done at the DHIA laboratory using AOAC methods (AOAC, 1984).

The protocol for this experiment was approved by the Institutional Animal Care and Use Committee at Washington State University (Pullman). Animals were weighed and BCS was measured at $30 \mathrm{~d}$ prepartum, and at 30, 90, and 270 DIM. Serum was collected from the coccygeal vessel for analysis of NEFA. Adipose tissue biopsies were taken from the tail head region (Smith and McNamara, 1989). Tissue to be used for gene expression analysis was immediately placed in Trizol reagent (Qiagen, Valencia, CA), homogenized (minimum of $30 \mathrm{~s}$ at maximal setting, then additional
Table 1. Diet composition for lactating Holstein dairy cattle at Knott Dairy Center

\begin{tabular}{|c|c|}
\hline Feedstuff & $\%, \mathrm{DM}$ basis \\
\hline Alfalfa haylage & 26.26 \\
\hline Alfalfa hay & 21.74 \\
\hline Whole cottonseed & 9.68 \\
\hline Concentrate mix & 42.32 \\
\hline \multicolumn{2}{|c|}{ Concentrate composition } \\
\hline Corn & 40.43 \\
\hline Barley & 18 \\
\hline Wheat & 10 \\
\hline Peas & 15 \\
\hline Soybean meal & 4 \\
\hline Corn gluten meal & 4.5 \\
\hline Megalac $^{1}$ & 2 \\
\hline Molasses & 2 \\
\hline Limestone & 0.5 \\
\hline Trace mineral salt & 1 \\
\hline Sodium bicarbonate & 2 \\
\hline Magox $^{2}$ & 0.4 \\
\hline 4-plex ${ }^{3}$ & 0.05 \\
\hline Vitamin D premix & 0.05 \\
\hline Vitamin A premix & 0.05 \\
\hline Vitamin E premix & 0.02 \\
\hline \multicolumn{2}{|l|}{ Totals, \% of DM } \\
\hline $\mathrm{DM}$ & 56.8 \\
\hline $\mathrm{CP}$ & 19.1 \\
\hline $\mathrm{NDF}$ & 28.3 \\
\hline $\mathrm{ADF}$ & 19.9 \\
\hline NFC & 42.2 \\
\hline $\mathrm{NE}_{\mathrm{L}}, \mathrm{Mcal} / \mathrm{kg}$ of $\mathrm{DM}$ & 1.60 \\
\hline $\mathrm{NE}_{\mathrm{G}}, \mathrm{Mcal} / \mathrm{kg}$ of DM & 1.12 \\
\hline
\end{tabular}

${ }^{1}$ Church and Dwight, Princeton, NJ.

${ }^{2}$ Baymag Inc., Calgary, Alberta, Canada.

${ }^{3}$ Zinpro Corp., Eden Prairie, MN.

30-s bursts until tissue was homogenized), and then placed on ice for later extraction of mRNA. Blood samples were allowed to clot at room temperature and then centrifuged $(2,700 \times g)$; serum was collected and frozen for later NEFA analysis.

\section{Body Fat and Energy Measures}

Incubations of adipose tissue were used to measure basal and stimulated rates of lipolysis. Adipose tissue was sliced and preincubated in $2 \mathrm{~mL}$ of Krebs-HEPES medium containing $2 \%$ BSA (fatty acid free) for $20 \mathrm{~min}$ to remove the effects of handling and slicing (McNamara and Hillers, 1986b; McNamara and Valdez, 2005). The medium was then removed and replaced with fresh medium and the tissue was incubated for another $2 \mathrm{~h}$. Basal media had no added stimulators. The response curve to $\beta$-adrenergic receptor binding was conducted using isoproteranol at $10^{-8}, 10^{-7}, 10^{-6}, 10^{-5}$, and $10^{-4} \mathrm{M}$. Adenosine deaminase $(6.6 \mathrm{U} / \mathrm{mL}$; \#116880, Calbiochem, San Diego, CA) and theophylline (1 mM; no. 200-3057, Sigma-Aldrich, St. Louis, MO) were included to maximize response to isoproteranol. Rates of lipolysis were 
expressed as glycerol release in nanomoles per gram of tissue per $2 \mathrm{~h}$.

Nonesterified fatty acids were measured enzymatically in serum with the NEFA-C kit (Wako Chemicals, Richmond, VA) with modifications and validated to use less serum and be more sensitive (McNamara and Hillers, 1986a; McNamara, 1988; Smith and McNamara, 1989).

Empty body fat (EBF) was calculated using an equation published by Waltner et al. (1994). The calculation was $\mathrm{EBF}=-122.1+0.21 \times(\mathrm{BW})+36 \times(\mathrm{BCS})$. This equation has an $\mathrm{R}^{2}$ of 0.78 and standard deviation of $15 \mathrm{~kg}$ for predicting EBF. Change in BCS, change in BW, and change in body fat were calculated as value at d 30,90 , or 270 DIM minus that at $30 \mathrm{~d}$ prepartum. We calculated energy balance at d -30 and 30 DIM using the following equation: energy balance $=-3.14-$ $0.009 \times \mathrm{NEFA}+0.341 \times \mathrm{DIM}-0.002 \times \mathrm{DIM}^{2}$, where NEFA is the concentration of NEFA (McGuire et al., 2002).

\section{Gene Expression}

Total RNA was extracted with the RNA-Easy minikit (75842, Qiagen). Sample quality was determined by resuspension in diethyl pyrocarbonate-treated water and spectroscopy at A260/A280. Quality of RNA was determined by denaturing electrophoresis (1.2\% agarose, $0.66 M$ formaldehyde, $20 \mathrm{~m} M 3$-(N-morpholino)propanesulfonic acid, $8 \mathrm{~m} M$ sodium acetate, and $1 \mathrm{~m} M$ EDTA) and examination of the $28 \mathrm{~S}$ and $18 \mathrm{~S}$ ribosomal bands after staining with ethidium bromide.

To prepare cDNA, $2-\mu \mathrm{g}$ samples of RNA were resuspended in $8 \mu \mathrm{L}$ of water with $1 \mu \mathrm{L}$ of $10 \mathrm{~m} M$ dNTP mix and $1 \mu \mathrm{L}$ of Oligo $(\mathrm{dT})_{12-18}(0.5 \mu \mathrm{g} / \mu \mathrm{L})$ and incubated at $65^{\circ} \mathrm{C}$ for $5 \mathrm{~min}$. Synthesis of cDNA followed with $2 \mu \mathrm{L}$ of $50 \mathrm{~m} M$ Tris- $\mathrm{HCl}$ (pH 8.3), $10 \mathrm{~m} M$ dithiothrietol, $3 \mathrm{mM}$ $\mathrm{MgCl}_{2}, 40$ units of $\mathrm{RNaseOut} \mathrm{recombinant} \mathrm{ribonuclease}$ inhibitor (Invitrogen, Carlsbad, CA), and 50 units of Superscript II reverse transcriptase (Invitrogen). Reactions were incubated at $42^{\circ} \mathrm{C}$ for $50 \mathrm{~min}$, and then at $70^{\circ} \mathrm{C}$ for $15 \mathrm{~min}$. Two units of Escherichia coli RNase $\mathrm{H}$ were added to each reaction and they were incubated at $37^{\circ} \mathrm{C}$ for $20 \mathrm{~min}$. The cDNA was aliquotted into $300-$ $\mu \mathrm{L}$ aliquots in snap-top microcentrifuge tubes and stored at $-80^{\circ} \mathrm{C}$. The PCR primers (Table 2 ) for $\beta$-actin, ribosomal $\mathrm{S} 2$, the $\beta$-adrenergic receptor subtypes, HSL, and perilipin were designed using Primer Express 2.0 (Applied Biosystems, Foster City, CA). The primers for the first 4 genes were designed according to published sequences; the PCR product for the perilipin primers was sequenced. The sequence was exported to FASTA format and was searched using BLAST (www.ncbi. nlm.nih.gov/BLAST/) to determine similar sequences
(Altschul et al., 1997). The BLAST search yielded a 93\% similarity for perilipin to Bos taurus adipocyte lipid droplet binding protein, GenBank accession numbers NM_001083699 and XM_598845.

\section{Real-Time PCR}

Per the manufacturer's recommendations, IQ SYBR Green (BioRad, Hercules, CA) was used for the realtime PCR analysis. Real-time PCR was performed on an iCycler (BioRad). Data were generated and plotted as $\Delta$-Rn, where $\Delta$-Rn $=\left(\mathrm{RFU}_{\text {sample }} / \mathrm{RFU}_{\text {passive reference }}\right.$ dye $)-\left(R U_{\text {sample initial }} / R U_{\text {passive reference initial }}\right)$, and RFU = relative fluorescence units. We calculated relative gene expression by using the reference gene ribosomal S2 protein. Relative gene expression was determined by calculating the difference between the cycle threshold (CT) value of the reference gene, ribosomal S2 protein, and that of the gene of interest. The difference across the time points was calculated as the difference in relative expression between $30 \mathrm{~d}$ prepartum and the 30 , 90 , and 270 DIM time points $(\Delta \Delta \mathrm{CT})$. The fold change over time was calculated using $2^{-\Delta \Delta \mathrm{CT}}$.

\section{Statistical Design and Analysis}

The experiment was designed to determine the effect of DIM and parity on gene expression and to determine the correlations, if any, among measures of gene expression, lipolysis, and animal performance (BW, BCS, EBF, energy balance, and milk production). The study was conducted and analyzed as a completely random design, with repeated measures, with parity and DIM as fixed effects. Data were analyzed using the following model: $\mu+\mathrm{A}(\mathrm{DIM})+\mathrm{B}($ Parity $)+(\mathrm{DIM} \times$ Parity $)$ using Proc GLM of SAS (SAS Institute, 1999), where A is the fixed effect of DIM at $30 \mathrm{~d}$ prepartum and 30,90 , or 270 DIM, and B is the fixed effect of parity at 1, 2, or 3 or greater. Statistical inferences were the same whether Proc GLM or Proc MIXED (SAS Institute, 1999) was used.

We also determined simple and multiple regression among measures of gene expression, rates of lipolysis, BCS, BW, EBF, calculated energy balance and change in BW, EBF, BCS, and calculated energy balance using Proc GLM of SAS.

\section{RESULTS AND DISCUSSION}

\section{$B W$ and $B C S$}

As expected, cows lost BCS, BW, and EBF in early lactation (Table 3) with recovery starting at 90 DIM and most animals having recovered the loss by 270 DIM. This is consistent with reported body fat use dur- 
Table 2. Primers used for real-time gene expression analysis

\begin{tabular}{|c|c|c|}
\hline Gene name & $\begin{array}{l}\text { GenBank } \\
\text { accession no. }\end{array}$ & Sequence, $3^{\prime}$ to $5^{\prime}$ \\
\hline$\beta 1$ adrenergic receptor $(\mathrm{AR})$ & AF188187 & $\begin{array}{l}\text { CGAGCAGAAGGCACTCAAGAC } \\
\text { CCAGGTCGCGGTGGAA }\end{array}$ \\
\hline$\beta 2 \mathrm{AR}$ & Z86037 & $\begin{array}{l}\text { CCCCAGGCACCGAAAACT } \\
\text { TCCCTTGTGAATCAATGCTATCA }\end{array}$ \\
\hline$\beta 3 \mathrm{AR}$ & X85961 & $\begin{array}{l}\text { AGGCAACCTGCTGGTAATCG } \\
\text { GTCACGAACACGTTGGTCATG }\end{array}$ \\
\hline Hormone-sensitive lipase & XM_592955 & $\begin{array}{l}\text { GAGTTTGAGCGGATCATTCA } \\
\text { TGAGGCCATGTTTGCTAGAG }\end{array}$ \\
\hline Perilipin & XM_598845 & $\begin{array}{l}\text { AGACACTGCCGAGTATGCTG } \\
\text { TGGAGGGAGGAGGAACTCTA }\end{array}$ \\
\hline
\end{tabular}

ing lactation (Drackley et al., 2006) and consistent with observed rates of lipolysis during this study. The mean loss of $44 \mathrm{~kg}$ of body fat signifies a fast rate of lipolysis during early lactation in these animals. These measures were taken to establish the whole-animal reference point for interpretation of adipose tissue metabolism and gene expression.

\section{Milk Production, Energy Balance, and NEFA}

The average $305 \mathrm{ME}$ for milk, fat, and protein was $14,254,511$, and $417 \mathrm{~kg}$ (Table 4). Milk and milk component production was greatest in second-lactation cows compared with first or third and higher. Milk production peaked at approximately 90 DIM, which correlated with the increases in lipolysis and expression of HSL and perilipin in adipose tissue (described below). Consistent with the BCS, BW, and EBF data indicating loss of body fat, NEFA concentrations increased at 30 DIM and then declined $(P<0.005$; Figure 1$)$. It is not surprising that NEFA concentrations declined by 90 DIM, even though milk production was peaking, because by this time DMI and energy intake have also increased to help meet the demand for milk synthesis. Primiparous animals had a mean NEFA concentration of $359 \mu \mathrm{mol} / \mathrm{L}$ at $30 \mathrm{DIM}$, whereas that second-lactation animals was $956 \mu \mathrm{mol} / \mathrm{L}$, and that third- or greater-

Table 3. Body condition score, BW, and empty body fat of pregnant and lactating dairy cattle

\begin{tabular}{lcccc}
\hline & \multicolumn{4}{c}{ DIM } \\
\cline { 2 - 5 } Measure & -30 & 30 & 90 & 270 \\
\hline BCS & 3.27 & 2.38 & 2.79 & 2.83 \\
SEM & 0.11 & 0.14 & 0.11 & 0.11 \\
BW, kg & 697 & $605^{*}$ & $652^{*}$ & 693 \\
SEM & 25 & 17 & 15 & 29 \\
Empty body fat, ${ }^{1} \mathrm{~kg}$ & 142 & $90^{*}$ & $115^{*}$ & 125 \\
SEM & 7 & 6 & 6 & 7 \\
\hline
\end{tabular}

${ }^{1}$ Calculated according to Waltner et al. (1994).

*Significantly different from value at $d-30$ at $P<0.05$. lactation animals was $2,340 \mu \mathrm{mol} / \mathrm{L}(P=0.006)$. Primiparous animals had consistently lower NEFA concentrations throughout lactation. Lower NEFA concentrations in primiparous animals have been shown previously (Grummer et al., 2004). This pattern has also been shown by Rabelo et al. (2005), for both high- and low-energy-density diets.

The energy balance calculated from BW, DIM, and NEFA concentration (McGuire et al., 2002) was -7.91 $\mathrm{Mcal} / \mathrm{d}$ at $30 \mathrm{DIM}$ and $8.17 \mathrm{Mcal} / \mathrm{d}$ at $90 \mathrm{DIM}$. At 30 DIM, the energy balance was approximately equal to a loss of $1 \mathrm{~kg} / \mathrm{d}$ of BW, and at 90 DIM, a gain of $1 \mathrm{~kg} /$ $\mathrm{d}$. These changes in the energy balance are within the range reported for dairy cattle and are consistent with the loss of BCS, BW, EBF, and increased NEFA concentrations in early lactation (Vernon et al., 1991; McNamara, 1994, 2004).

\section{Lipolysis}

Both basal and isoproteranol-stimulated incubations were performed. Isoproteranol is a selective stimulator for $\mathrm{B}_{2} \mathrm{AR}$, which was thought to be the primary subtype expressed by cattle. Basal lipolysis was greater during lactation, with lipolysis in the d 90 and 270 samples being approximately $10 \%$ greater $(P<0.05)$ than in the prepartum samples (Figure 2). The amount of body fat loss in early lactation limited the tissue available for incubations at $30 \mathrm{DIM}$; therefore, the small amount of data collected was not reported. At 90 DIM, stimulated rates were $60 \%$ greater $(P<0.05)$ than those at $30 \mathrm{~d}$ prepartum. Although basal lipolysis was greater at 270 DIM, the response to stimulus was similar to that observed prepartum. These results are consistent with the response to adrenergic stimulation being greater during lactation compared with prepartum (McNamara and Hillers, 1986b, 1989; Vernon et al., 1991). The adipose tissue of cows genetically selected for increased milk production is more responsive to $\beta$-adrenergic stimulation (McNamara and Hillers, 1986a,b, 1989). Cows that are producing more milk around the time of 
Table 4. Milk production of Holstein dairy cattle selected for gene expression analysis ${ }^{1}$

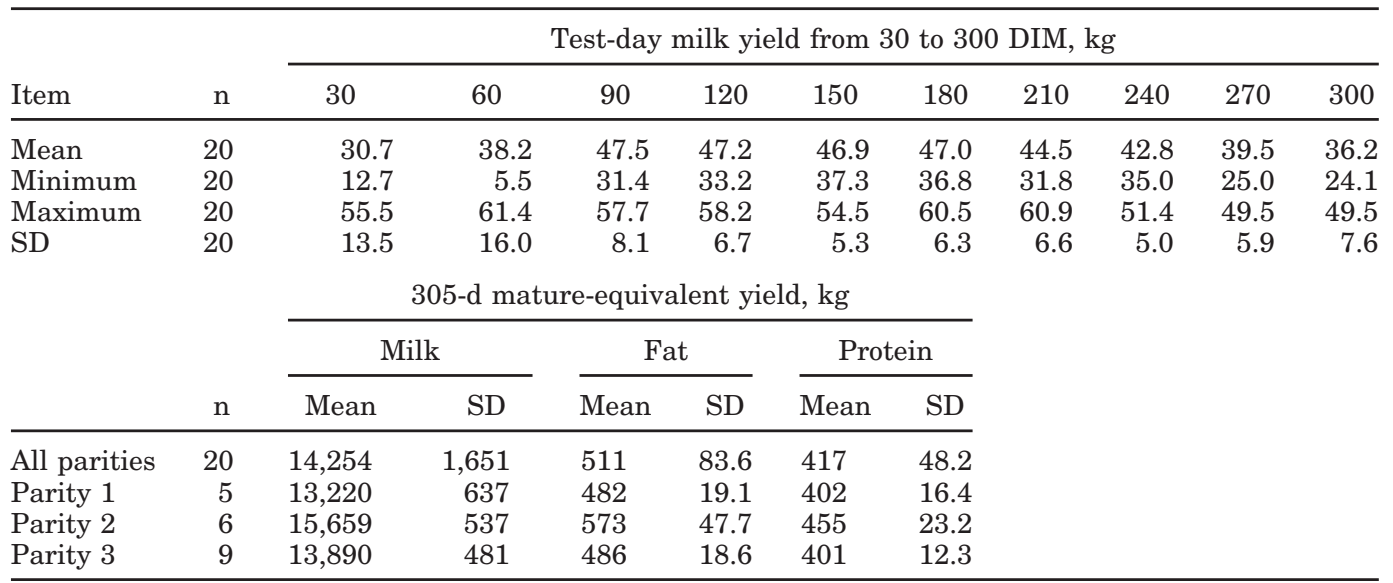

${ }^{1}$ Data compiled from DHIA records; DHIA, Provo, Utah.

measuring stimulated lipolysis also are more responsive to stimulation (McNamara and Hillers, 1989). As the cows selected for this work were the top producers in the herd, and were producing large quantities of milk, the rates of lipolysis measured here might be greater than those of lesser producing cows.

\section{Gene Expression}

Expression of $\beta$-Actin. $\beta$-Actin was originally selected to be the reference gene for the calculation of relative gene expression. $\beta$-Actin is a structural protein expressed in many cell types. It has been used with success for other relative expression studies (Bas et al., 2004). After $\beta$-actin expression was measured in these adipose tissue samples, however, it appeared not to be an ideal reference gene for adipose tissue during lactation because of the dramatic changes that occurred

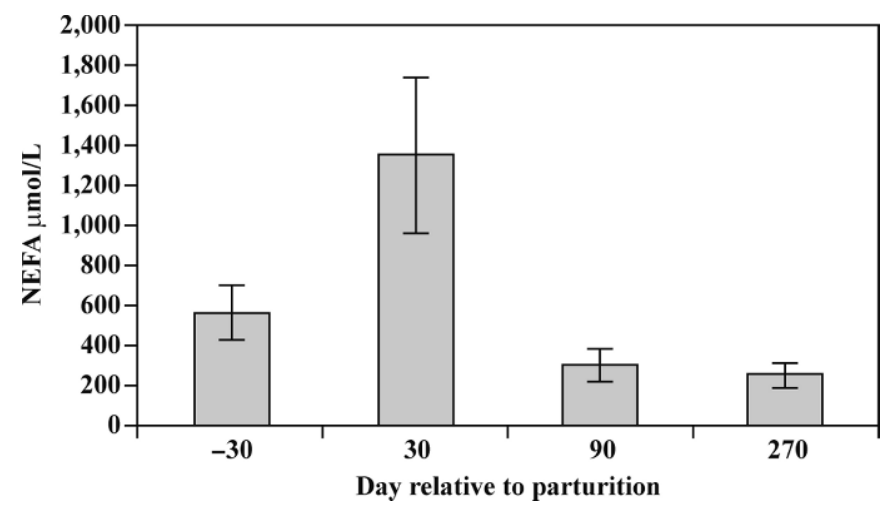

Figure 1. Nonesterified fatty acids in serum of pregnant and lactating Holstein dairy cattle; NEFA concentration increased $(P<0.05)$ during negative energy balance in early lactation and then decreased with increasing energy balance. in the tissue during the transition from nonlactating to lactating. The adipose tissue depots are utilized and absorbed in early lactation and restored later in lactation. These tissue adaptations resulted in large changes $(P<0.04$; effect of DIM $)$ in the CT values for $\beta$-actin. This change in $\beta$-actin expression is a novel and impressive finding, consistent with the mobilization of tissue and rebuilding of cells and adipose tissue when glucose and fatty acid balance increase in midlactation. After reviewing this result, $\beta$-actin was determined to not be suitable as the reference gene. Instead, the utility of ribosomal S2 protein was tested.

Following completion of the current study, another study demonstrated that expression of traditionally used housekeeping genes from bovine liver during late pregnancy and lactation was affected by physiological state, feed intake, and dietary treatment (JanovickGuretzky et al., 2007). Janovick-Guretzky et al. (2007) examined $\beta$-actin, GAPDH, $\beta$-glucuronidase, peptidylprolyl isomerase A, polyubiquitin, ribosomal protein S9, ribosomal protein L32, and $18 \mathrm{~S}$ ribosomal RNA and determined that ribosomal S9 protein was the most stably expressed gene across varying physiological conditions. It is not surprising that such variation in gene expression exists in various organs in this physiological situation because of the massive hormonal and neural adaptations to lactation. More importantly, scientists should determine which genes have altered expression rather than having a fixed normalization gene in all protocols.

Expression of Ribosomal S2 Protein. The second gene that was tested for use as a reference in the relative expression calculations was ribosomal S2 protein. This is a ribosomal structural protein and is expressed in many cell types. It had a consistent level of expres- 


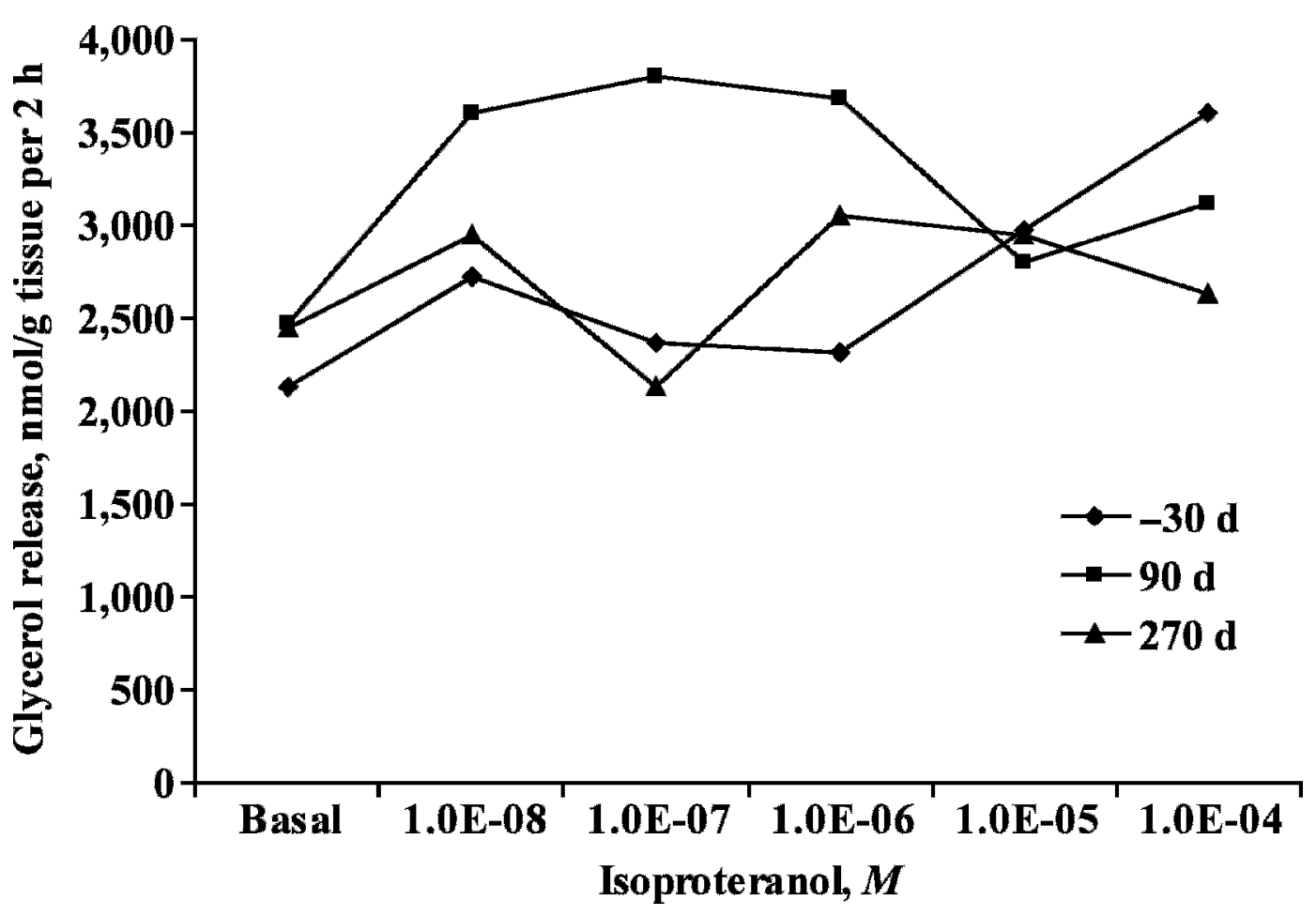

Figure 2. Glycerol release rate from in vitro incubations of adipose tissue from pregnant and lactating dairy cattle. Basal lipolytic rate was increased $(P<0.05)$ following parturition; and, at 90 DIM, peak levels of stimulated lipolysis increased $(P<0.05)$ by approximately $60 \%$ over basal levels.

sion across all time points; therefore, this gene was used as a reference for calculating relative expression.

Expression of $B_{1} \boldsymbol{A R}$. The $\mathrm{B}_{1} \mathrm{AR}$ subtype is intermediate to the $B_{3}$ and $B_{2} A R$ subtypes in its ability to induce lipolysis (Liggett and Raymond 1993; Castiella et al., 1994; McNeel and Mersmann, 1999). It is thought to have the lowest level of expression in cattle compared with the other 2 subtypes; this was consistent with the high CT values and thus the lowest relative abundance in this study. The $B_{1} A R$ was expressed at all time points and the relative expression increased at all postpartum sample points. The mean increase was 170,72 , and $112 \%$ at 30,90 , and 270 DIM (Figure 3) relative to expression at $d-30$. There was a trend for a parity effect $(P=0.15)$ on the change over time for expression of $\mathrm{B}_{1} \mathrm{AR}$, with the change for cows of third and greater parity (309, 120 , and $213 \%$ at 30,90 , and 270 DIM) being considerably greater than those of lower parity, the mean of first- and second-parity animals being 126 , 52 , and $84 \%$ at 30,90 , and 270 DIM. It is of note that cows of third and greater parity also had the highest NEFA concentrations.

Expression of $\boldsymbol{B}_{2} \boldsymbol{A R}$. The $\mathrm{B}_{2} \mathrm{AR}$ is the weakest of the 3 subtypes in its ability to induce lipolysis (Liggett and Raymond, 1993; Castiella et al., 1994; McNeel and Mersmann, 1999). However, in some species, the rela- tive abundance, and thus importance in lipolytic control, of $\mathrm{B}_{2} \mathrm{AR}$ is thought to be the greatest of the 3 subtypes (Mersmann, 1998). This was the case in this study, with $\mathrm{B}_{2} \mathrm{AR}$ having greater expression levels than $B_{1} A R$ or $B_{3} A R$. The $B_{2} A R$ receptor was expressed at all time points measured and the expression increased $(P=0.06)$ at all DIM. The mean increase was 75,121 , and $100 \%$ at 30,90 , and 270 DIM compared with $30 \mathrm{~d}$ prepartum (Figure 3). Expression of $\mathrm{B}_{2} \mathrm{AR}$ was greater in parity 3 compared with parity 2 and primiparous animals $(P=0.03)$.

Expression of $\boldsymbol{B}_{3} \boldsymbol{A R}$. The $\mathrm{B}_{3} \mathrm{AR}$ is the strongest of the 3 subtypes in its ability to induce lipolysis (Liggett and Raymond 1993; Castiella et al., 1994; McNeel and Mersmann, 1999). Its relative abundance is thought to be intermediate to that of the other 2 subtypes, which is consistent with results in this study. The $\mathrm{B}_{3} \mathrm{AR}$ was expressed at all time points measured and the relative expression increased $(P<0.05$; Figure 3$) 111,125$, and $69 \%$ at 30,90 , and 270 DIM. There was a parity by DIM interaction $(P=0.06)$ with $\mathrm{B}_{3}$ AR expression being less at 90 DIM in primiparous animals, but not multiparous cows. These results are consistent with an extended increase in plasma NEFA concentrations in multiparous cows. 


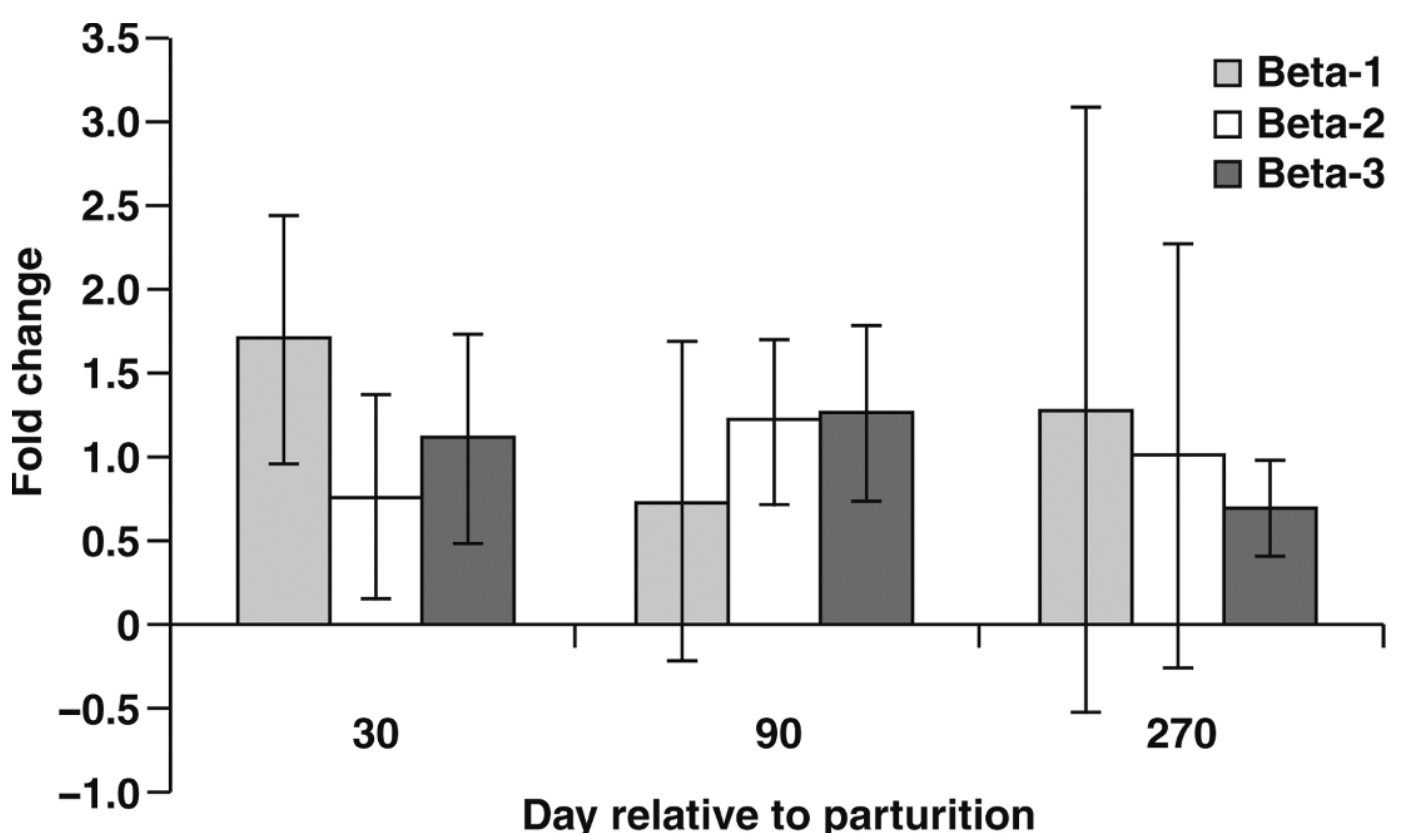

Figure 3. The expression of $\beta$-adrenergic receptor subtypes in lactating Holstein dairy cattle. Data are expressed as the fold change compared with the expression at $30 \mathrm{~d}$ prepartum. All of the $\beta$-adrenergic receptor (AR) subtypes were increased $(P<0.1)$ over prepartum levels. Expressions of $\mathrm{B}_{2} \mathrm{AR}$ and $\mathrm{B}_{3} \mathrm{AR}$ were greatest at $90 \mathrm{DIM}$ and $\mathrm{B}_{1} \mathrm{AR}$ was greatest at $30 \mathrm{DIM}$.

Expression of HSL. Hormone-sensitive lipase is the rate-limiting enzyme in the lipolytic pathway. (Yeaman, 1994). It is responsible for liberating the first 2 fatty acids from triacylglycerol in response to phosphorylation by protein kinase A. Hormone-sensitive lipase was expressed at all time points measured and the relative expression increased $(P=0.09)$ postpartum and was greatest in primiparous animals $(P=0.002)$. The mean increase was 180,359 , and $47 \%$ at 30,90 , and 270 DIM (Figure 4). The changes in HSL expression are consistent with its rate-limiting role in lipolysis, and also to the AR receptors and the fastest rate of stimulated lipolysis being at 90 DIM.

Expression of Perilipin. Perilipin is the cofactor for HSL. It is found on the lipid globule membrane of the adipocyte (Carmen and Victor, 2006; Wolins et al., 2006). Hormone-sensitive lipase binds perilipin before its activity in liberating fatty acids from triacylglycerol. We are unaware of any reports on the expression of perilipin in bovine adipose tissue. To create primers for perilipin, we used a computer-generated sequence based on known homology using the reference sequence (Genbank XM_598845) and splicing analysis functions of BLAST. The relative abundance of the gene was similar to that of the ribosomal S2 reference gene. Perilipin was expressed at all time points measured and the relative expression increased $(P=0.04)$ postpartum. The mean increase was $227,1,847$, and $126 \%$ at 30 ,
90, and 270 DIM compared with prepartum (Figure 5). There was a parity by DIM interaction, because animals of third and greater parity did not show any reduction $(P=0.02)$ in expression at 90 DIM, whereas the other parity groups did (but not to prepartum levels). Perilipin and HSL displayed a similar pattern of change with an increase at 30 DIM, a greater increase at 90 DIM, and the expression declining at d 270 in lactation (Figure 5).

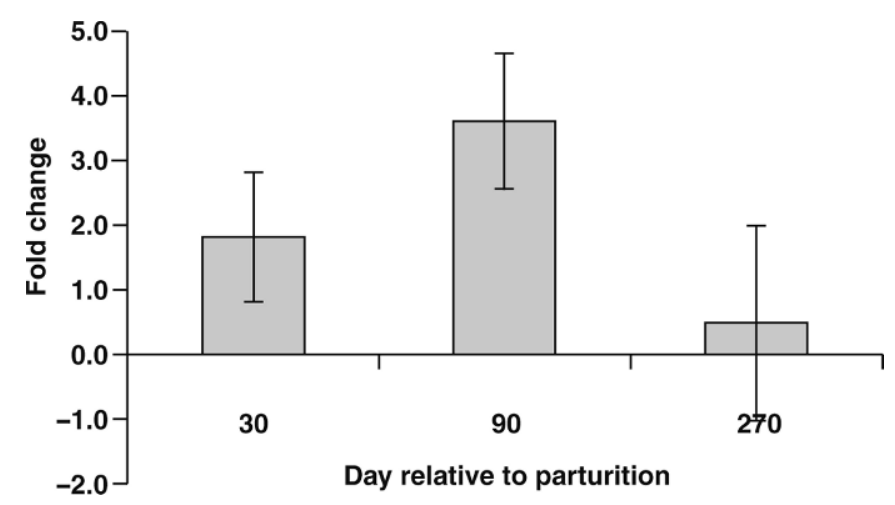

Figure 4. The expression of hormone-sensitive lipase (HSL) in lactating dairy cattle. Data are expressed as the fold change compared with expression at $30 \mathrm{~d}$ prepartum; HSL expression was increased $(P<0.05)$ over prepartum levels and was greatest at 90 DIM. 


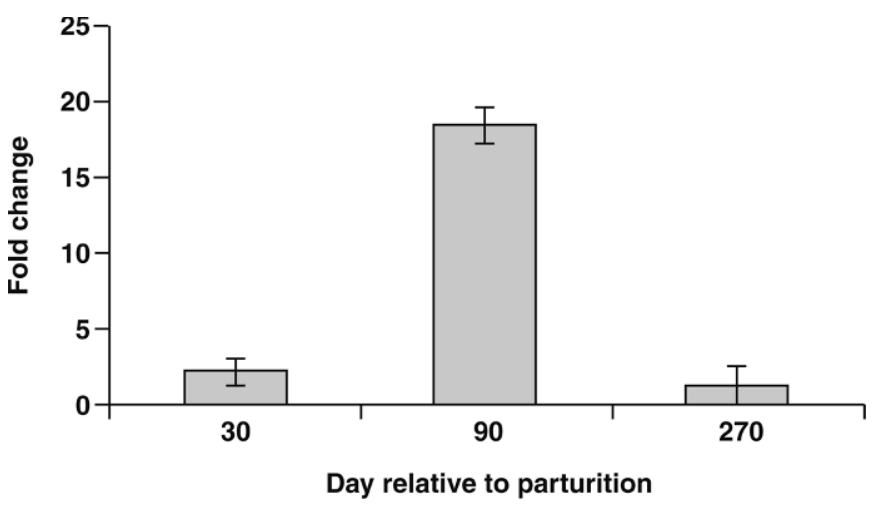

Figure 5. The expression of perilipin in lactating dairy cattle. Data are expressed as the fold change compared with expression at $30 \mathrm{~d}$ prepartum; perilipin expression was increased $(P<0.05)$ over prepartum levels and was greatest at 90 DIM.

\section{Correlations Among Lipolysis, Animal Level Measures, and Gene Eexpression}

We looked for relationships between the gene expression data and the physical and production characteristics measured. We examined simple and multiple regressions among measures of gene expression, rates of lipolysis, BCS, BW, EBF, NEFA, and calculated energy balance, and change in BW, EBF, BCS, and calculated energy balance.

In a model containing BW, BCS, and EBF, there was a relationship with the $\Delta \mathrm{CT}$ or relative expression for $\mathrm{B}_{2} \mathrm{AR}$. The equation was $\mathrm{B}_{2} \mathrm{AR} \Delta \mathrm{CT}=-1,844.4+3.17$ $\times \mathrm{BW}+-15.1 \times \mathrm{EBF}+544.3 \times \mathrm{BCS}\left(\mathrm{R}^{2}=0.10 ; P=0.25\right.$ for all variables). In a model with the same variables related to the $C T$ for the $B_{3} A R$, the equation was $B_{3}$ $\mathrm{AR} \mathrm{CT}=-2,518.7+4.4 \times \mathrm{BW}+-20.9 \times \mathrm{EBF}+753 \times$ $\mathrm{BCS}\left(\mathrm{R}^{2}=0.12 ; P=0.09\right.$ for all variables).

The relationship between expression of HSL and body fat use was somewhat stronger. Models containing the same variables for both HSL CT and HSL $\Delta \mathrm{CT}$ were $\mathrm{HSL} \mathrm{CT}=4,542.7+-7.7 \times \mathrm{BW}+37.0 \times \mathrm{EBF}+-1,335.4$ $\times \mathrm{BCS}\left(\mathrm{R}^{2}=0.27 ; P=0.1\right.$ for all variables $)$ and HSL $\Delta \mathrm{CT}=4,632.3+-7.9 \times \mathrm{BW}+38.0 \times \mathrm{EBF}+-1,368.9 \times$ $\mathrm{BCS}\left(\mathrm{R}^{2}=0.27 ; P=0.07\right.$ for all variables $)$.

The authors thought that expression of the genes for the receptors, HSL, and perilipin might relate more closely to rates of basal or stimulated lipolysis than to animal-level measures of body fat use. Thus, specific correlations were determined between expression of $\beta$ $\mathrm{AR}$ receptors and maximally stimulated lipolysis. The equations were: $\mathrm{B}_{1} \mathrm{AR} \mathrm{CT}=31.64+0.0005 \times$ stimulated lipolysis at $10^{-5}\left(\mathrm{R}^{2}=0.17 ; P=0.02\right)$; and $\mathrm{B}_{2} \mathrm{AR} \mathrm{CT}=$ $27.42+0.0003 \times$ stimulated lipolysis at $10^{-5}\left(\mathrm{R}^{2}=0.11\right.$; $P=0.07)$.

The absolute expression of HSL mRNA, as well as the expression relative to $\mathrm{S} 2$, was related to maximally stimulated lipolysis at an isoproteranol concentration of $10^{-5} \mathrm{M}$. The equations were HSL CT $=29.61+0.00087$ $\times$ stimulated lipolysis at $10^{-5}\left(\mathrm{R}^{2}=0.18 ; P=0.017\right)$ and HSL $\Delta \mathrm{CT}=24.24+0.00023 \times$ stimulated lipolysis at $10^{-5}\left(\mathrm{R}^{2}=0.12 ; P=0.05\right)$.

The multiple regression results reported here are consistent with our understanding of the multiple mechanisms of metabolic control. It would be surprising if, in fact, the expression of any one of these genes had a regression coefficient greater than approximately 0.50 , because we know that lipolysis is controlled by many factors posttranslationally. Multiple regressions of this type help us to understand the potential contribution to variation in metabolic rates of one process such as expression of a gene for a given protein.

The simple reaction of 1 triacylglycerol to 2 fatty acids and a monoacylglycerol (catalyzed by HSL) is one of the most important reactions in animal adaptability and survival (Yeaman, 1994). This reaction is affected by myriad environmental conditions from temperature to acute or chronic stress (exposure to various stimuli). Many endocrine and neural systems are involved in the modulation of this reaction. The reaction has been the focus of many studies leading to basic discoveries of biological regulation, from sympathetic nervous system activity, to adrenergic receptor subtypes, expression and binding capacity, to various mechanisms of cellular response elements such as the discovery of protein phosphorylation to activate or deactivate various enzymes. Much has been learned about the response of adipose tissue to adrenergic stimulation (McNamara, 1994), yet no one to date has reported whether expression of the genes coding for key proteins in this response are altered in lactation, one of the most important survival periods in mammals. The dairy cow is an excellent model for such study, because of the genetic potential to produce large volumes of milk, and thus to store and use body fat in support of milk production.

In addition to answering the qualitative question of whether an increase in expression of these genes occurs in lactation, we demonstrated that they are a significant mechanism of lipolytic control in lactation. It would not be expected (given that the response to adrenergic stimulation is controlled by several processes such as sympathetic nervous system activity, receptor binding, linkage to G-stimulatory and inhibitory proteins, and protein phosphorylation; Vernon, 1989; McNamara, 1994) that changes in expression would account for most of the variation in lipolytic rate. Given the multifactorial nature of metabolic control, including that on lipolysis, it is reasonable that the multiple regression analyses suggested that expression of these genes controlling lipolysis accounted for 10 to $25 \%$ of the variation 
in body fat use (based on the regression coefficients). Because the metabolism of body fat is so important to production, health, reproduction, longevity, and thus overall profitability, it is important to understand how much each step in the regulatory system contributes to control of body fat use. From this study, it is likely that the expression of $\beta$-adrenergic receptors and HSL play a major role in the regulation of lipolysis, and body fat use in lactating dairy cattle.

\section{CONCLUSIONS}

The expression of key genes involved in the catabolic pathways in adipose tissue is increased during lactation. Before this research, it had been shown that sensitivity of adipose tissue to lipolytic stimulus was increased during lactation (McNamara, 1994). The current study demonstrated that increased lipolysis is mediated, at least in part, by increases in the expression of the $\beta$-adrenergic receptor subtypes and the expression of HSL. We have also, for the first time, shown that perilipin is expressed within bovine adipose tissue and that it is upregulated during lactation. These homeorhetic adaptations to lactation allow for mobilization of stored lipid to meet the energy and lipid demands of milk synthesis. Dairy cattle are known to have a great variation in lipolysis and thus, greater incidence of metabolic and reproductive disorders. The current results on gene expression may lead to ways to select for animals that are metabolically more efficient or have an ability to respond with the proper level of lipolysis in adipose tissue.

\section{ACKNOWLEDGMENT}

We would like to thank Jan Vierck, John Swain, Michael O'Neill, and Chris Schactschneider for technical assistance.

\section{REFERENCES}

Altschul, S. F., T. Madden, A. Schaffer, J. Zhang, Z. Zheng, W. Miller, and D. Lipman. 1997. Gapped BLAST and PSI-BLAST: A new generation of protein database search programs. Nucleic Acids Res. 25:3389-3402.

AOAC. 1984. Official Methods of Analysis. 14th ed. Association of Official Analytical Chemists, Washington, DC.

Barnes, P. J. 1995. Beta-adrenergic receptors and their regulation. Am. J. Respir. Crit. Care Med. 152:838-860.

Bas, A., G. Forsberg, S. Hammerstrom, and M. L. Hammerstrom. 2004 . Utility of the housekeeping genes 18 s rRNA, beta-actin, and glyceraldehyde-2-phosphate-dehydrogenase for normalization in real-time quantitative reverse transcriptase-polymerase chain reaction analysis of gene expression in human $\mathrm{T}$ lymphocytes. Scand. J. Immunol. 59:566-573.

Bauman, D. E., and R. G. Vernon. 1993. Effects of bovine exogenous somatotropin in lactation. Annu. Rev. Nutr. 13:437-461.

Carmen, G. Y., and S. M. Victor. 2006. Signalling mechanisms regulating lipolysis. Cell. Signal. 18:401-408.
Carrington, E. F., M. Desautls, and J. M. Naylor. 2003. Beta-adrenergic stimulated lipolysis in pony adipocytes is exclusively via a B2subtype and is not affected by lactation. Comp Biochem. Physiol. A 36:311-320.

Castiella, L., P. Muzzin, J.-P. Revilli, D. Ricquier, and J.-P. Giacobino. 1994. Expression of beta-1 and beta-3 adrenergic-receptor messages and adenylate cyclase beta-adrenergic response in bovine perirenal adipose tissue during its transformation from brown into white fat. Biochem. J. 297:93-97.

Drackley, J. K., S. S. Donkin, and C. K. Reynolds. 2006. Major advances in fundamental dairy cattle nutrition. J. Dairy Sci. 89:1324-1336.

Grummer, R. R., D. G. Mashek, and A. Hayirli. 2004. Dry matter intake and energy balance in the transition period. Vet. Clin. North Am. Food Anim. Pract. 20:447-470.

Janovick-Guretzky, N. A., H. M. Dann, B. B. Carlson, M. R. Murphy, J. J. Loor, and J. K. Drackley. 2007. Housekeeping gene expression in bovine liver is affected by physiological state, feed intake, and dietary treatment. J. Dairy Sci. 90:2246-2252.

Liggett, S. B., and J. R. Raymond. 1993. Pharmacology and molecular biology of a adrenergic receptors. Baillieres Clin. Endocrinol. Metab. 7:279-305.

Londos, C., J. Gruia-Gray, D. L. Brasaemle, C. M. Rondinone, T. Takeda, N. K. Dwyer, T. Barber, A. R. Kimmel, and E. J. Blanchette-Mackie. 1996. Perilipin: Possible roles in structure and metabolism of intracellulae neutral lipids in adipocytes and steroidogenic cells. Int. J. Obes. Relat. Metab. Disord. 20(Suppl. 3):S97-101.

McGuire, M. A., B. Shafii, G. Orthel, and J. G. Geisy. 2002. Energy balance (EB) during the transition period in high producing Holstein cows. J. Anim. Sci. 80(Suppl. 1). J. Dairy Sci. 85(Suppl. 1):275. (Abstr.)

McNamara, J. P. 1988. Regulation of bovine adipose tissue metabolism during lactation 4. Dose-responsiveness to epinephrine as altered by stage of lactation. J. Dairy Sci. 71:643-649.

McNamara, J. P. 1994. Lipid metabolism in adipose tissue during lactation: A model of a metabolic control system. J. Nutr. 124:1383S-1391S.

McNamara, J. P. 2004. Research, improvement and application of mechanistic, biochemical, dynamic models of metabolism in lactating dairy cattle. Anim. Feed Sci. Technol. 112:155-176.

McNamara, J. P., B. Becker-Khaleel, and K. L. Parmley. 1992. Quantitative relationships between cyclic adenosine- $3^{\prime}, 5^{\prime}$-monophosphate and lipolysis in adipose tissue during the peripartum period. J. Dairy Sci. 75:1901-1913.

McNamara, J. P., and J. K. Hillers. 1986a. Regulation of bovine adipose tissue metabolism during lactation 1. Lipid synthesis in response to increased milk production and decreased energy intake. J. Dairy Sci. 69:3032-3041.

McNamara, J. P., and J. K. Hillers. 1986b. Regulation of bovine adipose tissue metabolism during lactation 2. Lipolysis response to milk production and energy intake. J. Dairy Sci. 69:3042-3050.

McNamara, J. P., and J. K. Hillers. 1989. Regulation of bovine adipose tissue metabolism during lactation 5. Relationships of lipid synthesis and lipolysis with energy intake and utilization. J. Dairy Sci. 72:407-418.

McNamara, J. P., and F. Valdez. 2005. Adipose tissue metabolism and production responses to calcium propionate and chromium propionate. J. Dairy Sci. 88:2498-2507.

McNeel, R. L., and H. J. Mersmann. 1999. Distribution and quantification of beta1, beta2, and beta3-adrenergic receptor subtype transcripts in porcine tissues. J. Anim. Sci. 77:611-621.

Mersmann, H. J. 1998. Overview of beta-adrenergic receptor agonists on animal growth including mechanisms of action. J. Anim. Sci. 76:160-172.

NRC. 2001. Nutrient Requirements of Dairy Cattle. 7th rev. ed. Natl. Acad. Sci., Washington, DC.

Rabelo, E., R. L. Rezende, S. J. Bertics, and R. R. Grummer. 2005. Effects of pre- and postfresh transition diets varying in dietary energy density on metabolic status of periparturient dairy cows. J. Dairy Sci. 88:4375-4383. 
SAS Institute. 1999. SAS/STAT User's Guide. Version 6.12. SAS Institute Inc., Cary, NC.

Smith, D. J., and J. P. McNamara. 1989. Lipolytic response of bovine adipose tissue to alpha and beta adrenergic agents during pregnancy and lactation. Gen. Pharm. 20:369-374.

Vernon, R. G. 1989. Endocrine control of metabolic adaptation during lactation. Proc. Nutr. Soc. 48:23-32.

Vernon, R. G., and E. Finley. 1988. Roles of insulin and growth hormone in the adaptations of fatty acid synthesis in white adipose tissue during the lactation cycle in sheep. Biochem. J. $256: 873-878$
Vernon, R. G., E. Finley, and P. W. Watt. 1991. Adenosine and the control of adrenergic regulation of adipose tissue lipolysis during lactation. J. Dairy Sci. 74:695-705.

Waltner, S. S., J. P. McNamara, and J. K. Hillers. 1994. Validation of indirect measures of body fat in lactating cows. J. Dairy Sci. 77:2570-2579.

Wolins, N. E., D. L. Brasaemle, and P. E. Bickel. 2006. A proposed model of fat packaging by exchangeable lipid droplet proteins. FEBS Lett. 580:5484-5491.

Yeaman, S. J. 1994. The multifunctional role of hormone-sensitive lipase in lipid metabolism. Adv. Enzyme Regul. 34:355-370. 